Received 07.05.2014 Reviewed 18.06 .2014 Accepted 24.06.2014

A - study design

B - data collection

C - statistical analysis

D - data interpretation

E - manuscript preparation

F - literature search

\section{Dynamics of water content in light bare soil in summer half-year in the period of 2003-2012 and its agro-meteorological determinants}

\author{
Małgorzata BINIAK-PIERÓG ABCDEF
}

Wrocław University of Environmental and Life Sciences, Faculty of Environmental Engineering and Geodesy, pl. Grunwaldzki 24, 50-363 Wrocław, Poland; tel. +48 71 320-19-48, e-mail: malgorzata.biniak-pierog@up.wroc.pl

For citation: Biniak-Pieróg M. 2014. Dynamics of water content in light bare soil in summer half-year in the period of 2003-2012 and its agro-meteorological determinants. Journal of Water and Land Development. No. 22 p. 4150 .

\begin{abstract}
The objective of the study was the estimation of decade variation of water content in layers with thickness of $0-10,0-20,0-40$ and $0-60 \mathrm{~cm}$ of a bare light brown soil in the summer half-year (May-October) in the 10year period of 2003-2012 against the background of agro-meteorological conditions. The study was based on results of measurement of the moisture of a bare soil with the use of the TDR method, sums of atmospheric precipitations and ground water levels, conducted in the area of the Agro- and Hydrometeorology Observatory of the Wrocław University of Environmental and Life Sciences, situated in Wrocław-Swojec. The analyses revealed slight variation of mean decade values of water content in the bare soil in the summer half-year during the ten-year period under analysis. Irrespective of the thickness of the soil layer, precipitation in the 10-year period of 2003-2012 had a highly significant effect on the water content in the $2^{\text {nd }}$ decade of July. In the case of soil layers with thickness down to $0-20 \mathrm{~cm}$ a statistically significant relation between soil water content and ground water levels was noted for the $3^{\text {rd }}$ decade of May, July, and in the $3^{\text {rd }}$ decade of September. In the layer with thickness of $0-60 \mathrm{~cm}$ the relations were statistically significant almost throughout the summer half-year, with the exception of the $1^{\text {st }}$ and $2^{\text {nd }}$ decades of May. Analysis of trends of mean water content of the bare soil over the 10-year period of 2003-2012 indicated their statistically significant increase in the case of most of the decades of the summer half-year only in soil layers with thickness of $0-10$ and $0-20 \mathrm{~cm}$.
\end{abstract}

Key words: ground water level, precipitation, soil water content, summer half-year, trends

\section{INTRODUCTION}

Soil moisture is one of the most important factors in the water cycle in the Earth surface - atmosphere plants system. It is indispensable not only to ensure suitable conditions for biological life, but also it determines numerous important soil processes, which guarantees correct growth and development of plants. Knowledge of the dynamics of soil moisture is important in studies concerning water management, and especially in those where it has a significant effect on the yielding of plants. Water retention plays an important role in the water balance of agricultural areas, especially those where high precipitation deficits are observed [ŁABĘDZKI 2006; NYC 1994].

Information about the dynamics of soil moisture under various crops facilitates the determination of their water balance and irrigation requirements in various development stages, which was the object of research by such authors as e.g. BARANOWSKI et al. [1994], HuPET and VANCLOOSTER [2002], KęDZIORA et al. [1997], KoŹMIŃSKI et al. [2002], ROBOCK et al. [2005].

The dynamics of soil water content is controlled primarily by agro-meteorological elements. Among those the leading role is played by atmospheric precipitations which are the main source of water supply 
for the soil profile, as well as the depth of the ground water table. Research in this area was conducted by e.g. BINIAK et al. [2011], CHEN and HU [2004], ŁABĘDZKI and ADAMSKI [2010], NIEMCZYK et al. [2010], OLSZEWSKA and PŁYWACZYK [1999], ROZBICKI [1998] and ŻYROMSKI [2001]. Long lasting precipitation deficit in the summer period with the usually high air temperatures, and the progressing process of urbanisation involving continuous expansion of nonpermeable surfaces, intensify the process of area evaporation, the occurrence of which is observed in recent years with increasing frequency [BURSZTA-ADAMIAK 2012; GÓRSKI 2006; KUNDZEWICZ et al. 2006; ŁABĘDZKI 2006; 2009]. Such a situation results usually in large losses in the economy, and in agriculture in particular. Hence, for the purpose of limitation of the effects of drought its monitoring is conducted in the vegetation season, primarily at a local scale [ŁABEDZKI, BAK 2011] but also for the whole territory of Poland [DOROSZEWSKI et al. 2012]. One of the fundamental elements of such monitoring is information about soil moisture.

The identification of the retention capacity of soils, time trends or periodicity of changes of retention requires studies directly monitoring soil moisture. For this reason, in the area of Agro- and Hydrometeorology Observatory of the Wrocław University of Environmental and Life Sciences daily measurements of soil moisture under two surfaces adopted as standard in agro-meteorology, bare and with grass cover, have been conducted continuously since 2002 . These surfaces are recommended as reference surfaces in both the national and global guidelines [JANISZEWSKI 1988; WMO-No 8]. In the case of bare soil surface, with no plant cover, we can assume with high probability that the soil water content is mainly dependent on agro-meteorological factors (especially precipitation and ground water levels) and it is the background for assessment of the impact of seasonal vegetation cover on the soil water balance. Studies concerning water content of bare soil have been carried out in several research centres [e.g. BINIAK 2004; KIMURA et al. 2005; NOVAK 2010; ROXY et al. 2010; THOMA et al. 2008; ŻYROMSKI 2001].

Thus the objective of the study was the estimation of decade variation of water content of a bare light brown soil in the summer half-year (May-October) in the ten-year period of 2003-2012.

\section{METHODS}

Soil moisture was measured with the use of the modern TDR method. It consists in measurement of the speed of propagation of electromagnetic wave with frequency above $50 \mathrm{MHz}$. The speed of propagation of electromagnetic wave generated by a TDR gauge depends on the dielectric constant $\left(K_{a}\right)$ of the medium studied [JONES et al. 2002; ROMANO 2014; SKIERUCHA et al. 2012].
In the area of the Observatory soil moisture measurements were conducted daily during the entire calendar year during morning observations at 8 depths in the soil profile $(10,20,30,50,60,80$ and $100 \mathrm{~cm})$. For analyses within the scope of this study four soil layers were selected, with thickness of $0-10,0-20$, $0-40$ and $0-60 \mathrm{~cm}$. In addition, daily measurements of the sum of atmospheric precipitations were conducted by classic Hellmann rain gauge, and of ground water level by a piezometer located in the area of the Observatory, the results of which were the basis for the calculation of decade values of those elements.

The soils in the experimental site are weakly loamy sands and light loamy sands overlying loam. According to the genetic classification they are arable brown soils developed from boulder loams, with surface horizon particle size distribution of weakly loamy sands, weakly diversified to the depth of $1 \mathrm{~m}$. The soils are characterised by good water properties and a high value of capillary rise. The field water capacity is $217.0 \mathrm{~mm}$ in the $0-100 \mathrm{~cm}$ soil layer [MAZIJ et al. 1964].

Diurnal values of soil moisture measured at depths from 10 to $60 \mathrm{~cm}$ during the period from the $1^{\text {st }}$ of May till the $31^{\text {st }}$ of October over the 10-year period of 2003-2012 were the basis for the calculation of water reserves in the soil layers chosen for the analyses in accordance to the formula:

$$
z=\frac{\hbar_{Q} w_{Q}}{10}
$$

where:

$\mathrm{z}$ - water content in soil layer, $\mathrm{mm}$;

$h_{0} \quad$ - thickness of soil layer, cm;

$W_{0}$ - mean moisture in the layer of thickness $h_{0}$ (TDR), $\%\left(\mathrm{~cm}^{3} \cdot \mathrm{cm}^{-3}\right)$.

Those values were the basis for the calculation of mean decade values of water content in those soil layers from the $1^{\text {st }}$ decade of May to the $3^{\text {rd }}$ decade of October. In the second stage of the study their variation in the summer half-year of the 10-year period covered by the study was analysed. Identical analyses were performed for the minimum and maximum mean decade values.

The next stage of the study was devoted to the analysis of relations between the mean decade values of water content in the selected soil layers and the decade sums of atmospheric precipitations, and the mean ground water table levels. Those analyses were conducted for the particular decades of the summer half-year, and for the consecutive years of the 10-year period of 2003-2012. The significance of the relations was estimated with the use of calculated values of coefficient of determination $R^{2}$ at significance level of $\alpha=0.05$, and their critical values were adopted after KRZYSZTOFIAK and URBANEK [1978]. In another variant, a comprehensive analysis of those relations in the successive decades of the summer half-year was performed with the use of multiple regression, by means 
of the computer program Statistica [Statsoft 2011]. The estimation of which variable provided the most information on the soil water content in the particular layers was conducted on the basis of the partial regression coefficients describing the contribution of a given independent variable to the explanation of the dependent variable.

The final stage of the analyses was the estimation of trends of water content in the soil layers selected for the study in the particular decades of the summer half-year over the 10-year period of 2003-2012. That analysis was based on linear trends, and their significance was estimated on the basis of the relevant coefficients of determination $R^{2}$. In addition, the tendency of occurrence of decades with minimum and maximum mean values of soil water content over the 10 -year period under study was estimated.

\section{RESULTS AND DISCUSSION}

For the purposes of this study a characterisation of precipitation conditions and mean levels of ground water table in the particular decades and whole summer half-years of the 10-year period of 2003-2012 was performed. The climatic norm adopted was the 30-year period of 1971-2000, preceding the years selected for the analyses. The sums of precipitations were characterised on the basis of the criterion proposed by KACZOROWSKA [1962], while the estimation of the ground water levels was made with the use of the criterion developed by this author for the purposes of this study on the basis of ground water levels in the area of the Observatory for the normative multi-year period. Fig. 1 presents the normative ground water levels for decade and the normal values of precipitation sums for the area of the research.

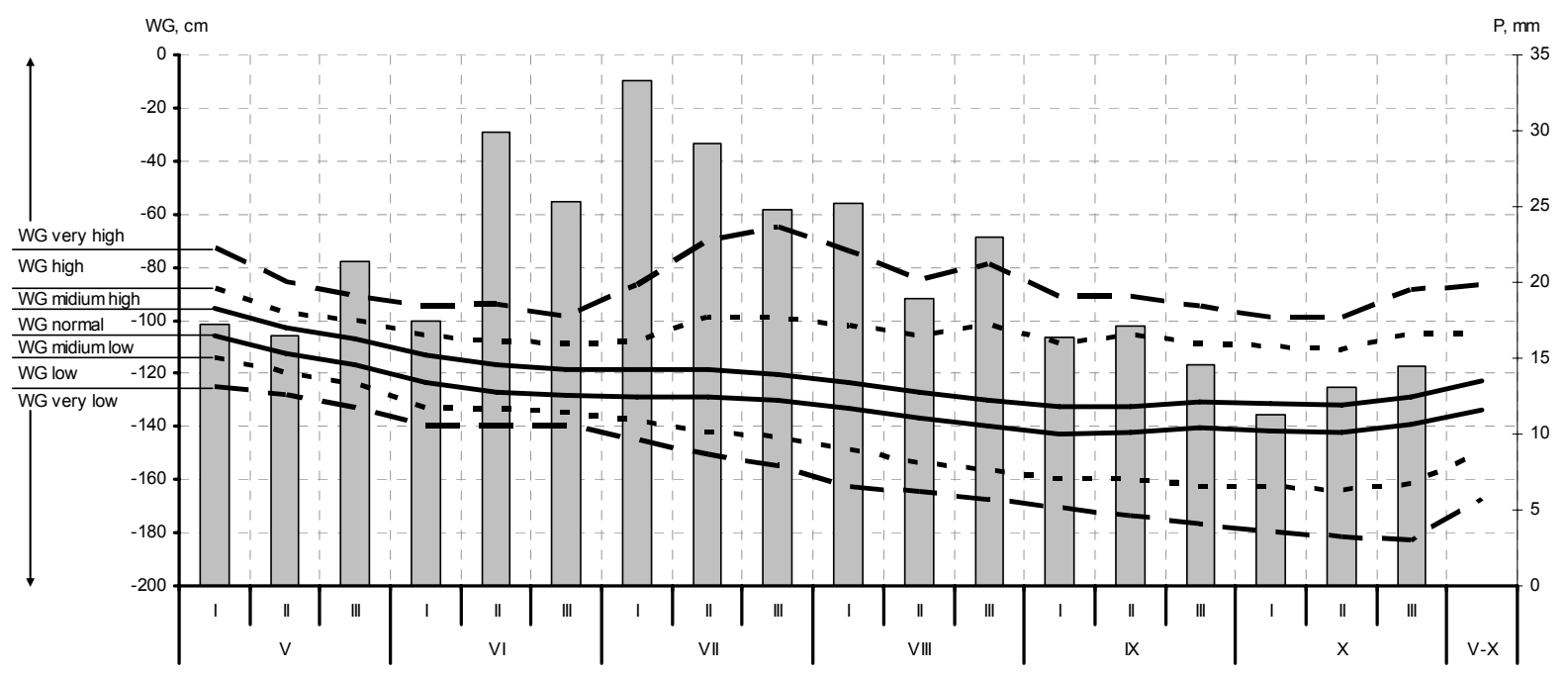

Fig. 1. The normative for ground water levels $W G$ and the values of precipitation sums $P$ from the climatic norm 1971-2000 in Wrocław-Swojec; source: own study

The analysis of the rainfall conditions revealed that the dominant ones were decades with normal rainfalls (38), followed by extremely dry decades (36) and dry decades (30) (especially in the years 20042006). In the analysed decades of the summer halfyear in the period of 2003-2012 the most frequent were very low, medium low and low levels of ground water table, especially in the years 2003, 2004, 2007, 2008 and 2012.

The analysis of the sums of precipitations in the whole summer half-years of the 10-year period studied showed that the summer half-year was very dry in 2004 $(259 \mathrm{~mm})$, and dry in $2003(307 \mathrm{~mm})$ and 2008 (302 $\mathrm{mm})$. Precipitation higher than the norm occurred in the last four years of the 10-year period under study in 2009 and 2010 the summer half-years were classified as very wet (505 and $501 \mathrm{~mm}$ adequately) and in 2011 and 2012 as wet (453 and $427 \mathrm{~mm}$ adequately). The mean levels of ground water table corresponded to low levels in the years $2004(-150 \mathrm{~cm}), 2007-2008$ $(-151,-164 \mathrm{~cm}$ adequately) and in $2012(-151 \mathrm{~cm})$, normal in $2005(-128 \mathrm{~cm})$, while in the years 2006 and 2009-2011 to medium high levels $(-120,-111,-$ 110 and $-120 \mathrm{~cm}$ adequately).

Figure 2 presents the decade variation of the mean, minimum and maximum values of water content in soil layers with thickness of $0-20$ and $0-60$ $\mathrm{cm}$. Minimum mean decade values of water content in the summer half-years in the 10-year period studied, with the exception of the top soil layer, were observed in the $3^{\text {rd }}$ decade of September $(16.8 \mathrm{~mm}$ in the layer of $0-20 \mathrm{~cm}, 40.8 \mathrm{~mm}$ in the layer of $0-40 \mathrm{~cm}$ and 68.1 in the layer of $0-60 \mathrm{~cm}$ ). The highest values were noted in May - in the $3^{\text {rd }}$ decade in the layers with thickness to $0 \div 40 \mathrm{~cm}(6.2 \mathrm{~mm}$ in the layer of $0-10 \mathrm{~cm}, 21.2$ in the layer of $0-20 \mathrm{~cm}$ and $49.8 \mathrm{~mm}$ in the layer of $0-40 \mathrm{~cm}$ ) while in the $1^{\text {st }}$ decade in the layer of $0-60 \mathrm{~cm}(87.8 \mathrm{~mm})$. Notably greater variability in the 10 -year period under analysis was characteristic of the extreme values of water content, especially the maximum values. Table 1 presents extreme and mean values of soil water content for analysed soil 
a)
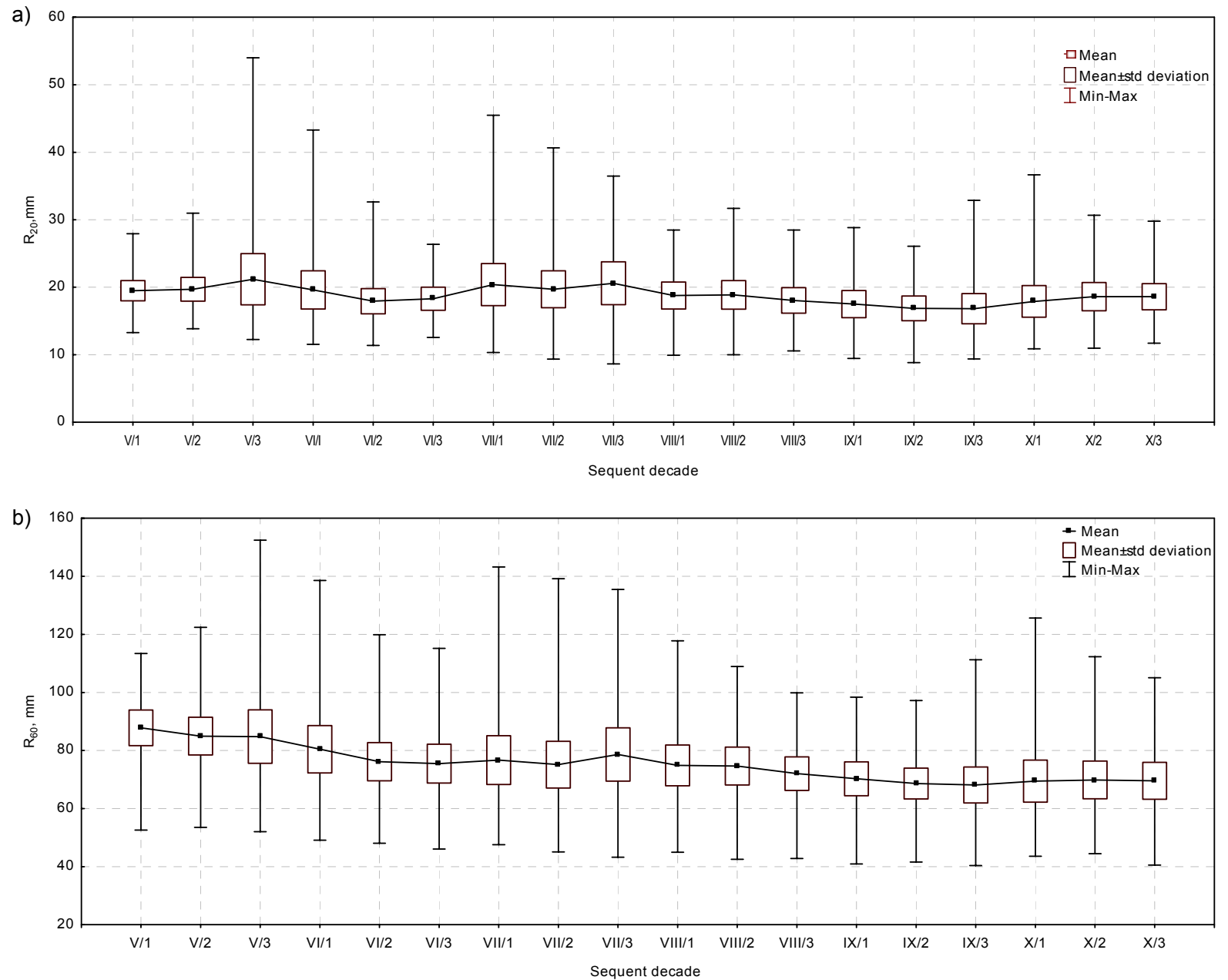

Fig. 2. Variability of decadal mean, minimum and maximum values of soil water content during summer half-year in years 2003-2012 in soil layer: a) 0-20 cm, b) 0-60 cm; source: own study

Table 1. Mean, minimum, maximum soil water content and the decade of their occurrence in particular summer half years of the period 2003-2012

\begin{tabular}{|c|c|c|c|c|c|c|c|c|c|c|c|}
\hline \multirow{2}{*}{$\begin{array}{c}\text { Soil layer } \\
\mathrm{cm}\end{array}$} & \multirow{2}{*}{ Value } & \multicolumn{10}{|c|}{ Soil water content $(\mathrm{mm})$ in the years } \\
\hline & & 2003 & 2004 & 2005 & 2006 & 2007 & 2008 & 2009 & 2010 & 2011 & 2012 \\
\hline \multirow{3}{*}{$0-10$} & $\min$ & $\begin{array}{l}1.8 \\
X / 3\end{array}$ & $\begin{array}{c}1.1 \\
\mathrm{IX} / 2\end{array}$ & $\begin{array}{l}1.7 \\
X / 3\end{array}$ & $\begin{array}{c}1.9 \\
\mathrm{VII} / 3\end{array}$ & $\begin{array}{l}1.9 \\
X / 2\end{array}$ & $\begin{array}{l}6.5 \\
X / 1\end{array}$ & $\begin{array}{c}5.7 \\
\mathrm{IX} / 3\end{array}$ & $\begin{array}{c}6.2 \\
\mathrm{VII} / 2\end{array}$ & $\begin{array}{c}4.9 \\
\mathrm{VI} / 2\end{array}$ & $\begin{array}{l}6.9 \\
X / 1\end{array}$ \\
\hline & $\max$ & $\begin{array}{l}2.8 \\
V / 2\end{array}$ & $\begin{array}{l}2.6 \\
V / 1\end{array}$ & $\begin{array}{c}4.2 \\
\mathrm{VI} / 1\end{array}$ & $\begin{array}{l}5.2 \\
V / 1\end{array}$ & $\begin{array}{l}4.1 \\
V / 2\end{array}$ & $\begin{array}{l}9.2 \\
V / 1\end{array}$ & $\begin{array}{l}15.5 \\
\text { VII/1 }\end{array}$ & $\begin{array}{l}20.0 \\
V / 3\end{array}$ & $\begin{array}{c}13.6 \\
\mathrm{VII} / 3\end{array}$ & $\begin{array}{l}10.7 \\
\mathrm{~V} / 1\end{array}$ \\
\hline & mean & 2.3 & 1.9 & 2.9 & 3.3 & 2.8 & 7.6 & 8.6 & 9.9 & 8.6 & 8.0 \\
\hline \multirow{3}{*}{$0-20$} & $\min$ & $\begin{array}{l}12.4 \\
X / 3\end{array}$ & $\begin{array}{c}8.8 \\
\text { IX/2 }\end{array}$ & $\begin{array}{c}12.4 \\
\mathrm{VIII} / 3\end{array}$ & $\begin{array}{c}8.7 \\
\mathrm{VII} / 3\end{array}$ & $\begin{array}{l}18.2 \\
X / 2\end{array}$ & $\begin{array}{l}15.5 \\
\mathrm{VI} / 2\end{array}$ & $\begin{array}{l}14.2 \\
\text { IX/3 }\end{array}$ & $\begin{array}{c}21.9 \\
\mathrm{VII} / 1\end{array}$ & $\begin{array}{l}17.9 \\
V / 3\end{array}$ & $\begin{array}{l}15.9 \\
X / 1\end{array}$ \\
\hline & $\max$ & $\begin{array}{l}16.6 \\
\mathrm{~V} / 2\end{array}$ & $\begin{array}{l}14.5 \\
X / 2\end{array}$ & $\begin{array}{l}16.6 \\
\mathrm{VI} / 1\end{array}$ & $\begin{array}{l}17.1 \\
\mathrm{~V} / 1\end{array}$ & $\begin{array}{c}25.6 \\
V / 2\end{array}$ & $\begin{array}{l}21.1 \\
\mathrm{~V} / 1\end{array}$ & $\begin{array}{l}45.5 \\
\text { VII/1 }\end{array}$ & $\begin{array}{l}54.0 \\
\mathrm{~V} / 3\end{array}$ & $\begin{array}{c}35.8 \\
\mathrm{VII} / 3\end{array}$ & $\begin{array}{l}27.9 \\
V / 1\end{array}$ \\
\hline & mean & 14.1 & 12.2 & 14.1 & 12.0 & 21.2 & 17.7 & 22.8 & 30.2 & 24.7 & 19.4 \\
\hline \multirow{3}{*}{$0-40$} & $\min$ & $\begin{array}{l}24.6 \\
X / 3 \\
\end{array}$ & $\begin{array}{l}29.2 \\
\mathrm{IX} / 2\end{array}$ & $\begin{array}{l}37.0 \\
X / 3\end{array}$ & $\begin{array}{c}33.1 \\
\mathrm{VII} / 3\end{array}$ & $\begin{array}{l}42.0 \\
\mathrm{X} / 2 \\
\end{array}$ & $\begin{array}{l}40.6 \\
\mathrm{X} / 1 \\
\end{array}$ & $\begin{array}{l}47.0 \\
\mathrm{IX} / 3\end{array}$ & $\begin{array}{c}52.3 \\
\mathrm{VII} / 2 \\
\end{array}$ & $\begin{array}{l}32.3 \\
\mathrm{VI} / 2 \\
\end{array}$ & $\begin{array}{l}33.8 \\
\mathrm{X} / 1 \\
\end{array}$ \\
\hline & $\max$ & $\begin{array}{l}32.1 \\
\mathrm{~V} / 2\end{array}$ & $\begin{array}{l}45.7 \\
\mathrm{~V} / 1\end{array}$ & $\begin{array}{l}49.6 \\
V I / 1\end{array}$ & $\begin{array}{l}60.8 \\
\mathrm{~V} / 1\end{array}$ & $\begin{array}{l}56.2 \\
\mathrm{~V} / 2\end{array}$ & $\begin{array}{l}61.0 \\
\mathrm{~V} / 1\end{array}$ & $\begin{array}{c}95.8 \\
\mathrm{VII} / 1\end{array}$ & $\begin{array}{c}103.4 \\
V / 3\end{array}$ & $\begin{array}{c}71.0 \\
\mathrm{VII} / 3\end{array}$ & $\begin{array}{l}43.4 \\
V / 1\end{array}$ \\
\hline & mean & 27.9 & 36.1 & 42.2 & 40.7 & 47.6 & 45.5 & 61.5 & 67.2 & 43.4 & 36.8 \\
\hline \multirow{3}{*}{$0-60$} & $\min$ & $\begin{array}{l}40.4 \\
\mathrm{IX} / 3\end{array}$ & $\begin{array}{l}54.7 \\
\text { IX/3 }\end{array}$ & $\begin{array}{l}62.7 \\
X / 3\end{array}$ & $\begin{array}{c}55.2 \\
\text { VII/3 }\end{array}$ & $\begin{array}{c}58.9 \\
\mathrm{X} / 2\end{array}$ & $\begin{array}{l}72.0 \\
\mathrm{X} / 1\end{array}$ & $\begin{array}{l}84.1 \\
\text { IX/3 }\end{array}$ & $\begin{array}{c}88.1 \\
\text { VII/2 }\end{array}$ & $\begin{array}{l}59.7 \\
\mathrm{VI} / 2\end{array}$ & $\begin{array}{c}51.3 \\
X / 1\end{array}$ \\
\hline & $\max$ & $\begin{array}{l}53.6 \\
\mathrm{~V} / 2\end{array}$ & $\begin{array}{c}91.0 \\
\mathrm{~V} / 1\end{array}$ & $\begin{array}{l}88.6 \\
V / 3\end{array}$ & $\begin{array}{c}99.6 \\
\mathrm{~V} / 1\end{array}$ & $\begin{array}{c}82.4 \\
\mathrm{~V} / 1\end{array}$ & $\begin{array}{c}113.4 \\
\mathrm{~V} / 1\end{array}$ & $\begin{array}{l}143.2 \\
\text { VII/1 }\end{array}$ & $\begin{array}{c}152.5 \\
\mathrm{~V} / 3\end{array}$ & $\begin{array}{l}115.2 \\
\text { VII/3 }\end{array}$ & $\begin{array}{l}69.8 \\
\text { V/1 }\end{array}$ \\
\hline & mean & 45.5 & 67.9 & 74.0 & 68.8 & 68.1 & 82.1 & 104.9 & 109.1 & 77.7 & 56.2 \\
\hline
\end{tabular}

Source: own study. 
layers and the decade of their occurrence in particular year of the period 2003-2012. The absolute maxima, irrespective of soil layer thickness, were noted in the $3^{\text {rd }}$ decade of May 2010, classified at the same time as very wet (precipitation sum of $33.0 \mathrm{~mm}$ ) and with very high mean level of ground water table $(-57 \mathrm{~cm})$. Their values amounted to, respectively, $20.0 \mathrm{~mm}$ in the case of the layer of $0-10 \mathrm{~cm}, 54.0 \mathrm{~mm}$ for the layer of $0-20 \mathrm{~cm}, 103.4 \mathrm{~mm}$ for the layer of $0-40 \mathrm{~cm}$ and $152.5 \mathrm{~mm}$ in the case of the layer of the greatest analysed thickness. The absolute minima of water content in the analysed soil layers were characterised by distinctly lower variation. They varied from 1.1 to 6.9 $\mathrm{mm}$ in the layer of $0-10 \mathrm{~cm}$ and from 40.4 to 88.1 $\mathrm{mm}$ in the layer with the greatest thickness (Fig. 2b). A high variability of the period of their occurrence was observed, taking into account the thickness variation of the soil layer (Tab. 1). In a majority of cases they occurred in decades with rainfall sums corresponding to, according to the adopted classification, periods from dry to extremely dry, and to low and very low levels of ground water table.

The analysis of relations between water content in the particular layers of bare soil and the sums of atmospheric precipitations in the summer half-years of the successive years of the 10-year period of 20032012 did not reveal statistically significant relations of those elements, as indicated by the values of the coefficient of determination $R^{2}$ below the threshold of significant value amounting to 0.40 . In the case of the relation of the mean decade soil water content in the layers selected for analysis and the levels of ground water table decidedly higher values of the coefficient of determination $R^{2}$ were obtained, indicating a significant effect of that element on their value. Irrespective of the summer half-year analysed, in soil layers with larger thickness the relations were statistically significant. The values of coefficient $R^{2}$ for the layer of $0 \div 40 \mathrm{~cm}$ varied from 0.50 in 2012 to 0.93 in 2005 , while in the case of the layer with thickness of 0-60 $\mathrm{cm}$ they assumed more uniform levels, in the range from 0.73 in 2011 to 0.97 in 2005 . Analyses of those relations for surface $(0-10 \mathrm{~cm})$ and arable $(0-20 \mathrm{~cm})$ layers of soil revealed that they were significant in most cases in those summer half-years in which the mean levels of ground water table were medium high (Fig. 1). In both cases the highest value of coefficient $R^{2}$ (above 0.80 ) was obtained for the year 2009, at medium high ground water table in the area of the Observatory $(-111 \mathrm{~cm})$. The linear trends determined indicated an increase of the relation during the 10 -year period under analysis in the case of the surface horizons, while for the layer with greater thickness an observable decreasing trend was noted, though the tendencies obtained were not statistically significant.

Two variants were applied in the estimation of the relations between the soil water content and sums of atmospheric precipitations versus the levels of ground water table. In the first variant they were esti- mated separately for each element, while in the second the analysis was conducted in a comprehensive manner, with the use of multiple regression. This allowed to indicate such periods in which the water content in soil layers with thickness from 0-10 to $0-60 \mathrm{~cm}$ in the 10-year period of 2003-2012 was affected significantly primarily by the precipitations or by the ground water table, and in a few cases by both of those elements. As an example, Fig. 3 presents the variation of the values of the coefficient of determination for the relations analysed in the first variant for soil layers with thickness of $0-20$ and $0-60 \mathrm{~cm}$.

Irrespective of the soil layer thickness, the sums of precipitations had a significant effect on soil water content in the $2^{\text {nd }}$ decade of July. In that decade highly significant relations were obtained for soil layers with thickness of $0-10$ and $0-20 \mathrm{~cm}\left(R^{2}=0.87\right.$ and $R^{2}=$ 0.79 , respectively), while for the layer with greater thickness $(0-40$ and $0-60 \mathrm{~cm})$ the values of the coefficient of determination were lower, though still statistically significant ( 0.51 and 0.44 , respectively). The analyses revealed that the water content in those soil layers was significantly affected also by the sums of precipitations in the $3^{\text {rd }}$ decade of September, and in that case the relations were greater, as indicated by the values of the coefficient of determination $R^{2}(0.65$ for the layer of $0-40 \mathrm{~cm}$ and 0.52 for $0-60 \mathrm{~cm})$. The water content in the arable layer of the soil $(0-20 \mathrm{~cm})$ was additionally significantly affected by that element in the $1^{\text {st }}$ and $3^{\text {rd }}$ decades of September (Fig. 3a). Analysis of the tendencies of those relations over the whole summer half-year indicated their increasing character, irrespective of the thickness of soil layers, but those were statistically insignificant.

A statistically significant effect of the level of ground water table on the water content in the surface layers of soil was observed in the $3^{\text {rd }}$ decade of May, in July and in the $1^{\text {st }}$ decade of October. The highest values of coefficients $R^{2}$ were obtained for the $1^{\text {st }}$ decade of July in the case of the layer of $0-10 \mathrm{~cm}(0.58)$, while for the arable layer the values were comparable for the $1^{\text {st }}$ and $3^{\text {rd }}$ decades of that month $(0.67$ and 0.68 , respectively) (Fig. 3a). Whereas, in the case of layers with greater thickness it was possible to indicate longer periods in which the levels of ground water table had a significant effect on the content of water in the soil. The characteristic intervals for the layer of $0 \div 40 \mathrm{~cm}$ were the periods from the $3^{\text {rd }}$ decade of May to the $1^{\text {st }}$ decade of August and from the $3^{\text {rd }}$ decade of September to the end of October. The values of significant coefficients of determination obtained varied from 0.42 in the $2^{\text {nd }}$ decade of June to 0.76 in the $3^{\text {rd }}$ decade of July. In the case of the layer with the greatest thickness $(0-60 \mathrm{~cm})$ the level of ground water table had a significant effect on the value of water content almost throughout the summer half-year, with the exception of the $1^{\text {st }}$ and $2^{\text {nd }}$ decades of May, and significant coefficients $R^{2}$ assumed values in the range from 0.40 in the $3^{\text {rd }}$ decade of August to 0.73 in the $3^{\text {rd }}$ decade of July (Fig. 3b). 
a)



b)



Fig. 3. Variability and the tendencies of determination coefficient $R^{2}$ for the relation between soil water reserves, precipitation $P$ and ground water level $W G$ in sequent decade during summer half-year of the period 2003-2012 for soil layer: a) 0-20 cm, b) 0-60 cm; source: own study

The comprehensive analysis of relations between soil water content and atmospheric precipitations and ground water levels conducted with the use of multiple regression revealed that in the $2^{\text {nd }}$ decades of July and August, $3^{\text {rd }}$ decade of September and in the $1^{\text {st }}$ and $2^{\text {nd }}$ decades of October both of the elements entered the regression equations obtained (Tab. 2). In a majority of cases the calculated values of partial coefficients of regression were statistically significant for ground water levels in the case of layers with thickness of $0 \div 20 \mathrm{~cm}$ and more.

In the $3^{\text {rd }}$ decade of May, $1^{\text {st }}$ and $3^{\text {rd }}$ decades of July, $1^{\text {st }}$ decade of August, $2^{\text {nd }}$ decade of September and $3^{\text {rd }}$ decade of October the levels of ground water table were the only variable in the equations obtained, irrespective of the thickness of soil layers (Tab. 2).

Table 2. The relation between soil water content in the layers: $0-10,0-20,0-40$ and $0-60 \mathrm{~cm}$ under bare soil, precipitation $P$ and ground water level $W G$ in summer half-year of the period 2003-2012

\begin{tabular}{|c|c|c|c|c|c|c|c|c|c|c|c|c|c|c|c|c|c|c|c|}
\hline \multirow{2}{*}{$\begin{array}{c}\text { Soil layer } \\
\mathrm{cm}\end{array}$} & \multirow{2}{*}{ Parameter } & \multicolumn{3}{|c|}{$\mathrm{V}$} & \multicolumn{3}{|c|}{ VI } & \multicolumn{3}{|c|}{ VII } & \multicolumn{3}{|c|}{ VIII } & \multicolumn{3}{|c|}{ IX } & \multicolumn{3}{|c|}{$X$} \\
\hline & & 1 & 2 & 3 & 1 & 2 & 3 & 1 & 2 & 3 & 1 & 2 & 3 & 1 & 2 & 3 & 1 & 2 & 3 \\
\hline \multirow{2}{*}{$0-10$} & $P$ & n.s. & n.s. & n.s. & n.s. & $*$ & * & n.s. & $* *$ & * & n.s. & * & $*$ & $*$ & n.s. & $*$ & $*$ & $*$ & n.s. \\
\hline & $W G$ & n.s. & n.s. & $* *$ & $*$ & n.s. & n.s. & $* *$ & n.s. & * & * & * & n.s. & n.s. & $*$ & $*$ & $* *$ & $*$ & $*$ \\
\hline \multirow{2}{*}{$0-20$} & $P$ & * & $*$ & n.s. & * & n.s. & * & n.s. & $* *$ & $*$ & n.s. & $* *$ & n.s. & $* *$ & n.s. & * & n.s. & $*$ & n.s. \\
\hline & $W G$ & n.s. & n.s. & $* *$ & $* *$ & $*$ & n.s. & $* *$ & $* *$ & $* *$ & $* *$ & $* *$ & n.s. & n.s. & * & * & $* *$ & $*$ & $*$ \\
\hline \multirow{2}{*}{$0-40$} & $P$ & n.s. & $*$ & n.s. & n.s. & n.s. & n.s. & n.s. & * & n.s. & n.s. & $*$ & n.s. & $*$ & n.s. & $* *$ & $*$ & $*$ & n.s. \\
\hline & $W G$ & * & n.s. & $* *$ & $* *$ & $* *$ & $* *$ & $* *$ & $* *$ & $* *$ & $* *$ & $* *$ & * & * & $*$ & * & $* *$ & $* *$ & $* *$ \\
\hline \multirow{2}{*}{$0-60$} & $P$ & n.s. & n.s. & n.s. & n.s. & n.s. & n.s. & n.s. & $*$ & n.s. & n.s. & $* *$ & n.s. & $*$ & n.s. & * & $*$ & $*$ & n.s. \\
\hline & $W G$ & $*$ & n.s. & $* *$ & $* *$ & $* *$ & $* *$ & $* *$ & $*$ & $* *$ & $* *$ & $* *$ & $*$ & $*$ & $* *$ & $*$ & $* *$ & $* *$ & $* *$ \\
\hline
\end{tabular}

Explanations: $*-\alpha=0.05, * *-\alpha=0.01$, n.s. - not significant.

Source: own study. 
Water deficits inhibit the growth and proper functioning of plants. Excessive water content is equally unfavourable. It causes an inhibition of plant growth and a reduction of yields, and contributes to the displacement of meso- and xerophilic plants by hydrophilic species. Moreover, excess of water leads to fungal diseases and plant infestation by pathogenic fungi, diseases of cereal plant species, poor fruition of plants, or even to decay of crops [KowALIK 2010]. For this reason the final stage of the analyses was the estimation of the tendencies of water content of bare soil in the successive decades of the summer half-year and of the times of occurrence of decades with minimum and maximum mean values of water content over the 10-year period under study. Irrespective of the thickness of soil layer and of the decade, increasing tendencies of water content were observed over the years 2003-2012. In the case of the surface horizon of the soil they were not statistically significant only in the $3^{\text {rd }}$ decades of May and July. The values of the coefficient of determination $R^{2}$ calculated for the other decades varied from 0.45 in the $1^{\text {st }}$ decade of June to 0.79 in the $2^{\text {nd }}$ decade of September. Analyses conducted for the soil layer with thickness of $0-20 \mathrm{~cm}$ indicated their greatest increase in the $1^{\text {st }}$ decade of May $\left(R^{2}=0.68\right)$. No statistically significant changes of water content were noted in the $3^{\text {rd }}$ decade of May, $1^{\text {st }}$ and $2^{\text {nd }}$ decades of June and July, and in the $1^{\text {st }}$ decade of October. In the case of soil layers with greater thickness the increasing tendencies of water content observed were not statistically significant.

A shift to earlier periods was observed in the times of occurrence of decades with minimum water content, irrespective of the thickness of soil layer analysed. Fig. 4 presents the tendencies of the times of occurrence of decades with the minimum and maximum values of water content in the soil layers of $0-20$ and $0-60 \mathrm{~cm}$. In the case of soil layers with thickness of $0-10$ and $0-20 \mathrm{~cm}$ the occurrence of decades with the minimum moisture shifted to the $3^{\text {rd }}$ decade of July, i.e. by 3 and 6 decades, respectively, over the 10 -year period under study. From the viewpoint of crop plants, greater importance should be attributed to the change in those times for layers with greater depth $-0-40$ and especially $0-60 \mathrm{~cm}$, where the greater part of the root mass of most crop plants is situated. In the first case, the time of occurrence of the decade with the minimum moisture shifted from the $2^{\text {nd }}$ decade of October to the $1^{\text {st }}$ decade of August $(7$ decades earlier), while in the second from the $1^{\text {st }}$ decade of October to the $3^{\text {rd }}$ decade of August (4 decades earlier).

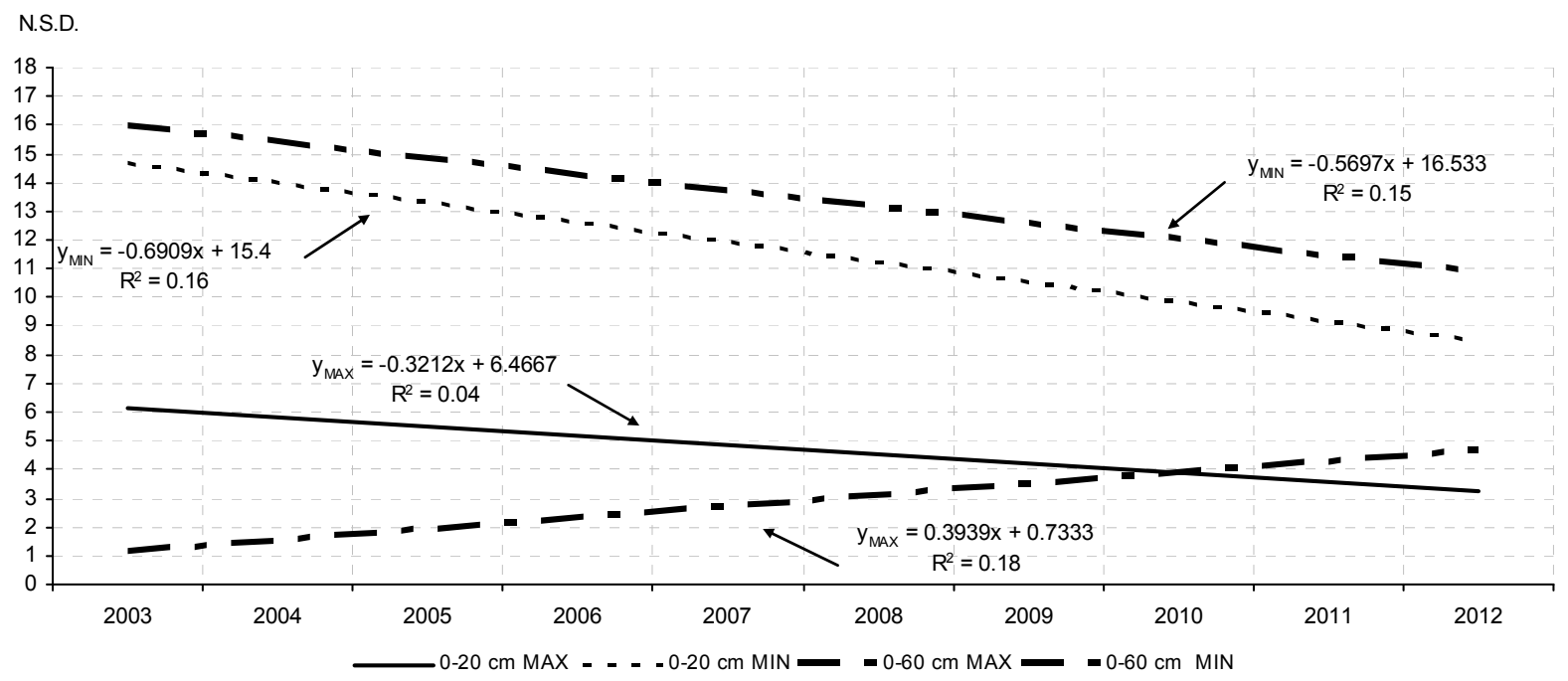

Fig. 4. Tendencies of the occurrence of decades (N.S.D.) of maximum and minimum values of soil water reserves in soil layers $0-20$ and $0-60 \mathrm{~cm}$ in summer half-year of the period 2003-2012; source: own study

Analysis of the changes in the times of occurrence of decades with the maximum soil moisture revealed their shift to earlier decades in the case of the surface horizons $(0 \div 10$ and $0 \div 20 \mathrm{~cm})$, while for the layers with greater thickness the shift was towards later decades. The smallest change was found for the arable layer of the soil $(0-20 \mathrm{~cm})$, from the $3^{\text {rd }}$ decade of June to the $3^{\text {rd }}$ decade of May (Fig. 4). In the case of layers of $0-40$ and $0-60 \mathrm{~cm}$ the occurrence of decades with the maximum soil moisture shifted over the 10 -year period under analysis from the $1^{\text {st }}$ decade of May to the $2^{\text {nd }}$ decade of June ( 4 decades later).
Due to the possibilities of the measurement techniques used in the past, published results of multi-year direct measurements of soil moisture mostly concerned decade periods (e.g. KoŹMINSKI, NIDZGORSKA-LENCEWICZ [2002], SPERANSKAYA [2009], WĄSEK [1980], ŻYROMSKI [2001]). It mainly resulted from the specificity and possibilities of the most frequently used measurement technique which was the thermo-gravimetric method. Its main drawback was the need for soil sampling, making it impossible to conduct measurements of soil moisture consistently at the same point. Homogeneity of the series was as- 
sumed, because mainly it referred to the measurement site, rather than a point as it is the case when field measurements are carried out using the TDR technique. Because of its availability, this non-destructive method has been used to conduct measurements of soil moisture for years. However, the use of that method, though non-destructive and allowing to conduct measurements at the same point and with any frequency (10 min, $1 \mathrm{~h}$, etc.), is limited on any larger scale because of quite high cost of measuring equipment.

Presented results of 10-year soil moisture measurements performed with TDR method are unique, because the decade means are developed on the basis of daily measurements, and not as it was when the thermo-gravimetric method was applied and measurement was performed every 10 days. Mean decade values obtained in this way represent the actual state of average soil moisture during this time interval. Therefore, the assessment of their variability with regard to daily precipitation totals - which make up the decade sums, and daily groundwater levels, from which decade values of that element are calculated, is very close to the actual conditions.

Research on soil moisture dynamics conducted with such a short time step and with the use of modern methods at foreign scientific centres for various surfaces in most cases relates to definitely shorter time periods (e.g. HUPET and VANCLOOSTER [2002], KIMURA et al. [2005]; NOVAK [2010]; PARENT et al. [2006]; RoXY et al. [2010]).

\section{SUMMARY}

The detailed analyses performed in this study for the bare soil allow to create a certain reference model for other surfaces covered with any vegetation in similar weather conditions. What is more, comparison of ground water levels and precipitation conditions with the values developed for the climatic norm gives a view on the frequency of events having a significant influence on soil moisture and, based on that indicator, on the water reserves in analysed soil layers.

Performed analyses indicated only slight variations in the mean decade values of water content of the bare soil in the summer half-year in the 10-year period of 2003-2012. Irrespective of the thickness of the soil layers, atmospheric precipitations in the 10-year period of 2003-2012 had a highly significant effect on water content in the $2^{\text {nd }}$ decade of July. In the case of soil layers with thickness of up to $0-20 \mathrm{~cm}$ a statistically significant relation of soil water content and ground water levels was found for the $3^{\text {rd }}$ decade of May, in July and in the $3^{\text {rd }}$ decade of September. In the layer with thickness of $0-60 \mathrm{~cm}$ the relations were statistically significant almost throughout the summer half-year, with the exception of the $1^{\text {st }}$ and $2^{\text {nd }}$ decades of May.

Analysis of tendencies of the mean water content of the bare soil over the 10-year period of 2003-2012 indicated their statistically significant increase in the case of most of the decades of the summer half-year only in the soil layers with thickness of $0-10$ and $0-20 \mathrm{~cm}$.

The analyses revealed a shift of the times of occurrence of decades with the minimum soil water content, over the 10-year period studied, to earlier decades: by from 3 decades for the layer of $0-10 \mathrm{~cm}$ to 7 in the case of the layer with thickness of $0-40 \mathrm{~cm}$. The times of occurrence of decades with the maximum soil water content shifted to earlier periods (on average by 4 decades) in the case of the surface and arable horizons, while in the case of soil layers with greater thickness - to later decades.

\section{REFERENCES}

Baranowski P., Kossowski J., Usowicz B. 1994. Przestrzenna zmienność wilgotności gleby na polach uprawnych [Spatial variability of soil water content in cultivated fields]. Zeszyty Problemowe Postępów Nauk Rolniczych. Z. 405 p. 9-19.

BiniaK-Pieróg M., Żyromski A., BARYŁA A. 2011. Ocena efektywności opadów atmosferycznych w kształtowaniu zasobów wody w glebie brunatnej nieporośniętej [An assessment of rainfall effectiveness in the formation of water resources in brown bare soil]. Woda-Środowisko-Obszary Wiejskie. T. 12. Z. 4(40) p. 45-58.

BINIAK M. 2004. Zmienność zasobów wodnych gleby pod powierzchnią nieporośniętą i trawiastą w okresie zimy 2002/2003 [Variability of soil water reserves under the bare soil and grassy surface in winter 2002/2003]. Acta Agrophysica. T. 3. Z. 1 p. 13-19.

BurszTA-ADAMiAK E. 2012. Analysis of the retention capacity of green roofs. Journal of Water and Land Development. No. 16 p. 3-9.

CHEN X., Hu Q. 2004. Groundwater influences on soil moisture and surface evaporation. Journal of Hydrology. Vol. 297 p. 285-300.

Doroszewski A., JAdCzyszyn J., Kozyra J., PudeŁko R., Stuczyński T., MizAK K., ŁopAtKa A., Koza P., GórSKI T., WrÓBlEWSKA E. 2012. Podstawy systemu monitoringu suszy rolniczej [Fundamentals of the agricultural drought monitoring system]. Woda-ŚrodowiskoObszary Wiejskie. T. 12. Z. 2(38) p. 77-91.

GóRSKI T. 2006. Zmiany warunków agroklimatycznych i długość okresu wegetacyjnego w ostatnim stuleciu. W: Długookresowe przemiany krajobrazu Polski w wyniku zmian klimatu i użytkowania ziemi [Changes of agroclimatic conditions and the lenght of vegetaion period during last 100 year period. In: Long term changes of Poland's landscape resulting from climate change and land management]. Eds. M. Gutry-Korycka, A. Kędziora, L. Starkel, L. Ryszkowski. Poznań. Komitet Narodowy IGBP p. 65-77.

HupeT F., VANCLOOSTER M. 2002. Intraseasonal dynamics of soil moisture variability within a small agricultural maize cropped field. Journal of Hydrology. Vol. 261 p. 86-101.

JANISZEWSKI F. 1988. Wskazówka dla posterunków meteorologicznych [Guide for meteorological sations]. Warszawa pp. 242.

JONES S.B., WRAITH J.M., OR D. 2002. Time domain reflectometry measurement principles and applications. Hydrological Processes. Vol. 16 p. 141-153. 
KaCZOROwSKa Z. 1962. Opady w Polsce w przekroju wieloletnim [Precipitation in Poland in long period averages]. Prace Geograficzne. Nr 33 pp. 112.

KęDZiora A., TUChOŁKa S., KAPUŚCIŃSKi J., PASZYŃSKi I., LEŚNY J., OLEJNIK J., MOCZKO J. 1997. Impact of plant cover on heat and water balance in agricultural landscapes located in humidity gradient. Roczniki Akademii Rolniczej w Poznaniu. T. 294 p. 271-301.

KimURA R., LiU Y., TAKAYAMA N., Zhang X., KamichiKa M., MATSUOKA N. 2005. Heat and water balances of the bare soil surface and the potential distribution of vegetation in the Loess Plateau, China. Journal of Arid Environments. Vol. 63 p. 439-457.

KowALIK P. 2010. Agrohydrologia obliczeniowa [Computational agrohydrology]. KGW PAN. Z. 33. ISBN $0867-$ 786 pp. 207.

KOŹMIŃSKI CZ., NIDZGORSKA-LENCEWICZ J. 2002. Kształtowanie się zasobów wody w profilu gleby lekkiej w Stacji Agrometeorologicznej w Lipkach koło Starogardu Szczecińskiego [Water resources in the sandy soil profile at the Agrometeorological Station in Lipki by Stargard Szczeciński]. Acta Agrophysica. Nr 78 p. 133-150.

KRZYSZTOFIAK M., URBANEK D. 1978. Metody statystyczne [Methods in statistics]. Warszawa. PWN. ISBN 83-0100917-9 pp. 415.

KundZEwicz Z., Szwed M., RADZIEJEWSKi M. 2006. Zmiany globalne i ekstremalne zjawiska hydrologiczne: powodzie i susze. W: Długookresowe przemiany krajobrazu Polski w wyniku zmian klimatu i użytkowania ziemi [Global changes and extreme hydrological events: floods and droughts. In: Long term changes of Poland's landscape resulting from climate change and land management]. Eds. M. Gutry-Korycka, A. Kędziora, L. Starkel, L. Ryszkowski. Poznań. Komitet Narodowy IGBP p. $169-180$.

ŁABĘDZKI L. 2006. Susze rolnicze. Zarys problematyki oraz metody monitorowania i klasyfikacja [Agricultural droughts. An outline of problems and methods of monitoring and classification]. Woda-Środowisko-Obszary Wiejskie. Rozprawy naukowe i monografie. Nr 17. ISBN 83-88763-63-6 pp. 109.

ŁABĘDZKI L. 2009. Expected development of irrigation in Poland in the context of climate change. Journal of Water and Land Development. No 13b p. 17-29.

ŁABĘDZKI L., ADAMSKI P. 2010. Związek między opadami uprzednimi a uwilgotnieniem gleby w uprawie buraków cukrowych na Kujawach [Relationship between previous period precipitation and soil moisture under sugar beet in Kujawy region]. Woda-Środowisko-Obszary Wiejskie. T. 10. Z. 3(31) p. 165-174.

ŁABĘDZKI L., BĄK B. 2011. Prognozowanie suszy meteorologicznej i rolniczej w systemie monitorowania suszy na Kujawach i w dolinie górnej Noteci [Predicting meteorological and agricultural drought in the system of drought monitoring in Kujawy and the upper Notec valley]. Infrastruktura i Ekologia Terenów Wiejskich. Nr 5 p. 19-28.

MaZiJ S., Kowalski J., WoźNY F., SZPAKOWSKI A., KRĘżEL J. 1965. Ekspertyza hydrogeologiczna i gleboznawcza pól ustalonych na Swojcu k. Wrocławia - Warunki hydrogeologiczne i glebowo-wodne pól ustalonych Instytutu Gospodarki Wodnej położonych na terenie RZD w Swojcu k. Wrocławia. Katedra Agro- i Hydrometeorologii Akademii Rolniczej we Wrocławiu (typescript).

NieMCZYK H., KowAlsKa B., MAJEWSKI G. 2010. Analiza zależności między aktualną wilgotnością gleby a wskaźnikiem opadów uprzednich i temperaturą powietrza
[Analysis of the relationship between actual soil moisture and anterior precipitation indexes and air temperature]. Przegląd Naukowy - Inżynieria i Kształtowanie Środowiska. Nr 1(47) p. 13-19.

NovaK M.D. 2010. Dynamics of the near-surface evaporation zone and corresponding effects on the surface energy balance of a drying bare soil. Agricultural and Forest Meteorology. Vol. 150 p. 1358-1365.

NYC K. 1994. Rola retencji gruntowej w bilansowaniu zasobów wodnych [Soil retention part in water resources balance]. Zeszyty Naukowe Akademii Rolniczej we Wrocławiu. Konferencje V. Nr 248 p. 248-251.

OlszewsKa B., PŁywaCZYK L. 1999. Groundwater participation in water management of the soils in the Odra valley in the region of the Brzeg Dolny dam. Roczniki Akademii Rolniczej w Poznaniu. T. 310. Nr 20(2) p. 211-221.

Parent A.C., Anctil F., Parent L.E. 2006. Characterisation of temporal variability in near-surface soil moisture at scales from $1 \mathrm{~h}$ to 2 weeks. Journal of Hydrology. Vol. 325 p. $56-66$.

Robock A., Mu M., Vinnikov K., Trofimova I.V., AdAMENKO T.I. 2005. Forty - five years of observed soil moisture in Ukraine: No summer desiccation (yet). Geophysical Research Letters. Vol. 32 p. 3401-3405.

Romano N. 2014. Soil moisture at local scale: Measurements and simulations. Journal of Hydrology. Vol. 516 p. 6-20.

RoXy M.S., Sumitranandan V.B., RenUKa G. 2010. Variability of soil moisture and its relationship with surface albedo and soil thermal diffusivity at Astronomical Observatory, Thiruvananthapuram, south Kerala. Journal of Earth System Science. Vol. 119. No 4 p. 507-517.

RozBiCKI T. 1998. Związek między wskaźnikami opadu i wilgotnością gleby dla ekosystemu stepu strefy umiarkowanej [The relationship between precipitation indexes and soil moisture in the temperate grassland ecosystems]. Przegląd Naukowy Wydz. Melioracji i Inżynierii Środowiska SGGW w Warszawie. Z. 16 p. 98104.

Skierucha W., SŁawiŃSKi C., WilcZeK A., ŻYromsKi A., BINIAK-PIERÓG M. 2012. Telemetryczny system pomiaru wilgotności gleby działający w technice TDR [Telemetric system for the measurement of soil moisture based on the TDR technique]. Woda-Środowisko-Obszary Wiejskie. T. 12. Z. 2(38) p. 257-267.

SPERANSKAYA N.A. 2009. Soil moisture changes in non boral European Russia: in situ data. In: Regional aspects of climate-terrestrial-hydrologics interactions in nonboreal eastern Europe. Eds. P.Y. Groisman, S.V. Ivanov. Springer p. $165-174$.

StatSoft, Inc. 2011. Statistica (data analysis software system). Version 10.

ThOMA D.P., MORGan M.S., Bryant R., RAhMAN R.R., Holifield collins C.D., Keefer T.O., Noriega R., OSMan I., SkiRvin S.A.M., Tischler M.A., BOSCH D.D., Starks P.J., Peters-Lidard C.D. 2008. Appropriate scale of soil moisture retrieval from high resolution radar imagery for bare and minimally vegetated soils. Remote Sensing of Environment. Vol. 112 p. 403414.

WĄSEK A. 1980. Zasoby wodne w górnej warstwie aeracji a wskaźnik wilgotności gruntu [Water storage in the upper layer of aeration zone and soil moisture index]. Przegląd Geofizyczny. Nr 25 (33). Z. 1 p. 71-78. 
WMO-No 8. Guide to Meteorological Instruments and Methods of Observation updated 2010. Geneva. ISBN 978-92-63-10008-5 pp. 681.

ŻYrOMSKI A. 2001. Czynniki agrometeorologiczne a kształtowanie się zasobów wody w glebie lekkiej z podsią- kiem wód gruntowych w okresie wiosennym [The effect of agrometeorological conditions on water supplies in light soil characterized by spring ascent]. Zeszyty Naukowe Akademii Rolniczej we Wrocławiu. Nr 404. Rozprawy 178. ISSN 0867-7964 pp. 134.

\section{Malgorzata BINIAK-PIERÓG}

\section{Zmienność zasobów wodnych w glebie lekkiej nieporośniętej w półroczu letnim w latach 2003-2012 i jej uwarunkowania agrometeorologiczne}

\section{STRESZCZENIE}

Słowa kluczowe: opady, pótrocze letnie, stany wody gruntowej, tendencje, zasoby wodne gleby

Celem pracy była ocena dekadowej zmienności zasobów wody w glebie lekkiej brunatnej nieporośniętej w półroczu letnim (maj-październik) w dziesięcioleciu 2003-2012 w warstwach miąższości $0-10,0-20,0-40$ i 0-60 cm na tle warunków agrometeorologicznych. W pracy wykorzystano wyniki pomiarów wilgotności gleby nieporośniętej z zastosowaniem metody TDR, sum opadów atmosferycznych i stanów wody gruntowej, prowadzonych na terenie Obserwatorium Agro- i Hydrometeorologii Uniwersytetu Przyrodniczego we WrocławiuSwojcu. Przeprowadzone analizy wykazały nieznaczne wahania średnich dekadowych wartości zasobów wody gleby nieporośniętej w półroczu letnim w przyjętym do analiz 10-leciu. Bez względu na miąższość warstwy gleby opady atmosferyczne w okresie 2003-2012 istotnie wpływały na zasoby wody w 2 . dekadzie lipca. W warstwach gleby o miąższości do $0-20 \mathrm{~cm}$ stwierdzono istotną statystycznie zależność zasobów wody w glebie i stanów wody gruntowej w 3 . dekadzie maja, lipcu oraz 3 . dekadzie września. $\mathrm{W}$ warstwie miąższości $0-60 \mathrm{~cm}$ relacje te były istotne statystycznie niemal w całym półroczu letnim, z wyjątkiem 1. i 2. dekady maja. Na podstawie analizy tendencji średnich zasobów wody w glebie nieporośniętej w okresie 10-lecia 2003-2012 stwierdzono ich istotny statystycznie wzrost $\mathrm{w}$ większości dekad półrocza letniego jedynie w warstwach gleby miąższości $0-10$ i $0-20 \mathrm{~cm}$. 